\title{
Annual variation in the foraging behaviour of thick-billed murres in relation to upper-ocean thermal structure around St. George Island, Bering Sea
}

\author{
Nobuo Kokubun ${ }^{1, *}$, Akinori Takahashi ${ }^{1}$, Motohiro Ito $^{2}$, Kei Matsumoto ${ }^{2}$, \\ Alexander S. Kitaysky ${ }^{3}$, Yutaka Watanuki ${ }^{2}$ \\ ${ }^{1}$ National Institute of Polar Research, 10-3 Midori-cho, Tachikawa, Tokyo 190-8518, Japan \\ ${ }^{2}$ Graduate School of Fisheries Sciences, Hokkaido University, 3-1-1 Minato-cho, Hakodate, Hokkaido 040-0821, Japan \\ ${ }^{3}$ Institute of Arctic Biology, University of Alaska, Fairbanks, Irving 311, Fairbanks, Alaska 99503, USA
}

\begin{abstract}
We studied the foraging behaviour of adult thick-billed murres Uria lomvia as they reared their chicks at St. George Island, Alaska, USA, relative to the thermal structure of the nearby ocean water column in the summers 2004, 2006, and 2007 using data recorders attached to the birds. The thermal structure of the upper ocean varied substantially among the years. Satellite-derived sea surface temperature (SST) and water temperature at depths $>40 \mathrm{~m}$ were higher in 2004 than in 2006 and $2007\left(9.1,8.3\right.$ and $7.8^{\circ} \mathrm{C}$ for mean SST; $5.1,4.4$, and $2.2^{\circ} \mathrm{C}$ for median bottom temperature, respectively). We recorded a strong thermocline in 2004 and 2007, but not in 2006. Nonetheless, the thermocline was one of the important foraging habitats in all years. The foraging behaviour of thick-billed murres appeared to vary with annual variation in the intensity of the thermocline and water temperature at depth and evidently with associated vertical distribution of prey. Birds spent more time foraging in stratified waters and dived to around thermocline depth (and deeper in 2007) in 2004 and 2007. However, the birds used both stratified and mixed waters in 2006 and were less likely to dive to thermocline depth. Main prey items delivered to chicks varied among years. Sandlance (53\% of observed items) and pollock (23\%) predominated in 2004, compared with cephalopods $(23 \%)$, flatfishes $(17 \%)$ and pollock (15\%) in 2006, and cephalopods (62\%), pollock (16\%) and sculpins (9\%) in 2007.
\end{abstract}

KEY WORDS: Diving behaviour - Thermocline $\cdot$ Climate change $\cdot$ Ecological response $\cdot$ Seabirds . Bering Sea

\section{INTRODUCTION}

The distribution of prey and the foraging behaviour of seabirds are often correlated with the vertical thermal structure (e.g. depth and intensity of thermoclines) of ocean habitats (cf. Hunt et al. 1990, Ballance et al. 2001, Spear et al. 2001). Fine-scale studies of these correlations have been difficult, however, owing to limits in technological tools. The recent development of small data recorders that can be attached to birds now allows the documentation of the foraging behaviour of freeranging birds and physical characteristics of their ocean habitats (e.g. Charrassin \& Bost 2001, Watanuki et al. 2001, Daunt et al. 2006). Inter-annual comparison of foraging behaviour of seabirds in relation to changes in upper-ocean structure can provide new insights into the physical and biological oceanographic properties that affect foraging seabirds.

A large number of seabirds breed in the Bering Sea, one of the most productive continental shelf areas in the world's oceans (Sowls et al. 1978, Hunt et al. 1981). Though several studies have discussed variation in diet or breeding success in relation to the ocean environment (Decker et al. 1995, Byrd et al. 2008, Sinclair et al. 2008), the functional relationships between the ocean environment, distribution of prey and foraging behaviour of seabirds has not been well studied. Takahashi et al. (2008) found that foraging thick-billed mur- 
res Uria lomvia, one of the most abundant predators in the southeastern Bering Sea, often dived to just below the thermocline, perhaps because both zooplankton and fish prey are more concentrated there (Takahashi et al. 2008). Annual variability in physical oceanography in the Bering Sea affects the abundance and distribution of prey, and perhaps food competition among top predators (Hunt et al. 1986, Wyllie-Echeverria \& Ohtani 1999, Stabeno et al. 2007). Thus, the characteristics of the foraging habitat should be linked with variation in the thermal structure near the ocean surface.

The objective of the present study was to evaluate the annual variations in sea surface temperature (SST), thermocline intensity, and water temperature at depth and determine how they correlate with the foraging behaviour of thick-billed murres that breed in the southeastern Bering Sea. We documented water temperature profiles and the diving and flight behaviour of murres with recording instruments attached to freeranging birds. We also obtained SST data from earthorbiting satellite sensors and data on the diets of birds from direct observations of prey that adults delivered to their chicks.

\section{MATERIALS AND METHODS}

Study site. We conducted studies at the large colony of thick-billed murres (Kitaysky et al. 2000) at High Bluff on St. George Island $\left(56^{\circ} 35^{\prime} \mathrm{N}, 169^{\circ} 35^{\prime} \mathrm{W}\right)$, in the southeastern Bering Sea, Alaska, USA, in late summer 2004 (3 to 12 August), 2006 (2 to 8 August), and 2007 (4 to 10 August). These periods coincided with the chickrearing stage. We reanalysed some results reported by Takahashi et al. (2008) to compare with our data from 2006 and 2007.

Deployment of recorders. We used depth-temperature-acceleration data loggers (W190-D2GT; each housed in a cylindrical container, $15 \mathrm{~mm}$ diameter, $53 \mathrm{~mm}$ length, mass $17 \mathrm{~g}$; Little Leonardo) to record behavioural and environmental data during the foraging excursions of adult birds. We captured chick-rearing birds with a $5 \mathrm{~m}$ noose pole and then attached a logger, with Tesa ${ }^{\circledR}$ tape (Tremblay et al. 2003, Takahashi et al. 2008 ) to the belly of each of 18 birds in 2004, 7 in 2006, and 9 in 2007. Handling time for each bird was less than $14 \mathrm{~min}$. We programmed the loggers to record measurements of depth and temperature every second, and surge (tail-to-head) and heave (ventral-to-dorsal) accelerations at 16 or $64 \mathrm{~Hz}$ (Watanuki et al. 2006). We recaptured the birds and removed the loggers when birds returned from foraging excursions between 1 and $6 \mathrm{~d}$ after they were initially tagged and released.

Information on general chick diet was recorded from direct visual observations of adults (both with and without data loggers) carrying prey items to their chicks. Prey items were visually identified to the lowest taxonomic level possible during observation or later from photographs.

Foraging trips and dive bouts. During the chickrearing period, parent thick-billed murres alternate foraging at sea with guarding their chicks at the colony. We defined the duration of foraging trips (to the nearest second) as the time between departure and return of birds to the colony. These events were obvious as a rapid shift in recorded temperature correlated with recorded changes in body angle of the birds (Takahashi et al. 2008). We classified the behaviour of murres during the foraging trip as diving, flight, or sitting on the water surface using acceleration, depth and temperature data (Watanuki et al. 2006). The timing and duration of flight events was determined from the acceleration data. Foraging trips consist of several series of dives, separated by flight events (Falk et al. 2000). Assuming that the birds move among the foraging locations by flying, we considered the series of dives as 'dive bouts' (Takahashi et al. 2008). We also estimated the potential maximum foraging ranges of each year by calculating the average flight duration during foraging trips. We assumed the birds flew in a straight route between the colony and foraging locations with a flight speed of $65 \mathrm{~km} \mathrm{~h}^{-1}$ (Benvenuti et al. 1998).

Upper-ocean thermal structure at foraging locations. Four parameters for upper-ocean thermal structure were recorded at foraging locations: (1) SST, (2) thermocline depth, (3) thermocline intensity, and (4) water temperature at depth. The temperature sensor of the loggers recorded SST when the birds were on the sea surface, as they were attached on the belly of the birds. When the birds dived, vertical temperature profiles were determined for each dive bout, using data from the deepest dive (only where dives were $>20 \mathrm{~m}$ depth) of the dive bouts. Because the temperature sensors had a slow response time (90\% time constant $=15 \mathrm{~s}$ ), we corrected the temperature data for the response time following Daunt et al. (2003) and Takahashi et al. (2008). We estimated depth of the thermocline from the vertical temperature profiles, by locating the depth where $\mathrm{d} T / \mathrm{d} D$ was the maximum $(T$ : temperature, $D$ : depth), only when $\mathrm{d} T / \mathrm{d} D$ was $>0.25^{\circ} \mathrm{C}$ (Takahashi et al. 2008). We defined thermocline intensity as the difference between average temperatures above and below the thermocline, then calculated average water temperature below $40 \mathrm{~m}$ (thermocline depth was shallower than $40 \mathrm{~m}$ for most dives each year) and assumed that value to be water temperature at depth.

SST data were also obtained from satellite remotesensing, from the Ocean Watch homepage, National Oceanic and Atmospheric Administration (http://las. 
pfeg.noaa.gov/oceanWatch/oceanwatch.php). Reanalysed monthly SSTs for August of each year $\left(0.1 \times 0.1^{\circ}\right)$ were taken from 'Multiple-Satellite Blended Products' and averaged within the potential foraging range of the birds for each year. The SST data were compared with the data collected using data loggers. In addition, the location of the edge of the sea ice at the point of maximum extent during the prior spring in each year was recorded (from Aqua AMSR-E data). The date of the maximum sea ice extent in each year was reported by Overland et al. (2008).

Diving behaviour. For each dive we determined dive depth, dive duration, bottom time (the time between the start and end of the time when birds showed no changes in depth), and diving efficiency, i.e. bottom time/(dive duration + post-dive surface intervals), for dives that had a $<300 \mathrm{~s}$ post-dive surface interval only, cf. Takahashi et al. (2003). A dive was considered to occur when dive depth exceeded $0.5 \mathrm{~m}$ (Watanuki et al. 2001, Takahashi et al. 2008). We compared actual dive depth and the overall frequency distribution of dive depths among years using non-parametric Mood's median test and Kolmogorov-Smirnov tests since the variance was not consistent and errors did not fit a normal or gamma distribution. We used Minitab ${ }^{\circledR}$ V 14 and Statview ${ }^{\circledR}$ V 5.0 software for statistical analyses.

\section{RESULTS}

\section{Recorder and data recovery}

We recaptured and recovered recorders from 12 birds in 2004, 7 in 2006, and 4 in 2007. The remaining birds were not observed after the planned timing of recapture; their chicks either died, fledged early, or were abandoned. In addition, in 2006 one of the recaptured birds lost its chick during the study period and one recorder failed to collect data. Thus, we analysed data from 12 recorders in 2004, 5 in 2006, and 4 in 2007. The body masses of these birds, before loggers were attached, did not vary among years (ANOVA, $F=2.1, \mathrm{p}=0.15$ ). Overall, we recorded 51 foraging trips in 2004, 11 in 2006, and 10 in 2007.

\section{Characteristics of foraging trips and dive bouts}

The durations of foraging trips, dive bouts, and inbound flights did not vary among years (Table 1). However, the total flight duration and number of dive bouts per foraging trip was longer and greater in 2007 than in 2004 (Table 1). Based on the total flight duration during a foraging trip, the potential maximum foraging ranges of birds from the colony were $35.5 \mathrm{~km}$ in 2004, $41.1 \mathrm{~km}$ in 2005 , and $64.0 \mathrm{~km}$ in 2007.

\section{Characteristics of the water column used by the birds}

There was significant variation in satellite-derived SST within the potential foraging range of the birds in August among years (Fig. 1, ANOVA, $F=27.6$, $\mathrm{p}<0.01$ ). SST was highest in 2004, intermediate in 2006, and lowest in 2007. The location of the sea ice edge around the island at its maximum extent each spring was farthest north in 2004, intermediate in 2006, and farthest south in 2007 (Fig. 1).

Water temperature recorded by the loggers also varied among years (Fig. 2). The birds encountered higher SSTs in 2004 than in 2006 and 2007 (Fig. 2A,C,E, Table 2). We compared SST values from the recorders with those obtained from earth-orbiting satellites within the potential maximum foraging range. Birds spent more time in areas of greater SST than would be expected from the frequency distribution of SST from satellites, especially in 2004 and 2007 (Fig. 2A,C,E). The temperature at depth $>40 \mathrm{~m}$ in the water column (below the thermocline) was lowest $\left(0\right.$ to $\left.5^{\circ} \mathrm{C}\right)$ in 2007 , intermediate $\left(3\right.$ to $\left.7^{\circ} \mathrm{C}\right)$ in 2006 and highest $\left(4\right.$ to $8^{\circ} \mathrm{C}$ ) in 2004 (Fig. 2B,D,F, Table 2). The thermocline depth at the locations of dive bouts was shallowest $(15 \mathrm{~m})$ in 2007, intermediate (18 m) in 2004, and deepest (20 m) in 2006. However, the difference was not always significant (Table 2). Thermocline intensity (difference between average temperatures above and below the thermocline) was also highest $\left(5.7^{\circ} \mathrm{C}\right)$ in 2007 , intermediate $\left(4.2^{\circ} \mathrm{C}\right)$ in 2004 and lowest $\left(2.9^{\circ} \mathrm{C}\right)$ in 2006 (Table 2$)$.

The birds encountered higher SST during trips when they spent a longer time in flight (Fig. 3). The asymptotic exponential curve fitted to the data shows that the birds experienced higher SSTs in 2004 than in 2006

Table 1. Uria lomvia. Foraging trips and dive bouts in the summers of 2004, 2006 and 2007. Data are mean $\pm \mathrm{SE}^{*}{ }^{*} \mathrm{p}<0.05$

\begin{tabular}{|c|c|c|c|c|c|c|c|}
\hline \multirow{2}{*}{\multicolumn{2}{|c|}{$\begin{array}{c}\text { Year No. of } \\
\text { trips }\end{array}$}} & \multirow[b]{2}{*}{ Trip } & \multicolumn{3}{|c|}{ Duration (h) } & \multirow{2}{*}{$\begin{array}{l}\text { No. of } \\
\text { dive } \\
\text { bouts }\end{array}$} & \multirow{2}{*}{$\begin{array}{c}\text { No. of } \\
\text { dive bouts } \\
\text { per trip }\end{array}$} \\
\hline & & & Total flight & $\begin{array}{l}\text { Inbound } \\
\text { flight }\end{array}$ & $\begin{array}{l}\text { Dive } \\
\text { bouts }\end{array}$ & & \\
\hline 2004 & 51 & $7.4 \pm 0.8$ & $1.1 \pm 0.1$ & $0.50 \pm 0.04$ & $1.6 \pm 0.2$ & 139 & $2.7 \pm 0.3$ \\
\hline 2006 & 11 & $9.3 \pm 1.3$ & $1.3 \pm 0.3$ & $0.33 \pm 0.05$ & $1.5 \pm 0.3$ & 45 & $4.1 \pm 1.2$ \\
\hline 2007 & 10 & $9.8 \pm 1.8$ & $2.0 \pm 0.4$ & $0.59 \pm 0.08$ & $1.3 \pm 0.4$ & 62 & $5.7 \pm 1.8$ \\
\hline \multicolumn{8}{|c|}{ 1-way ANOVA, Scheffe's post-hoc test ( $p$-value) } \\
\hline \multirow{3}{*}{\multicolumn{2}{|c|}{$\begin{array}{l}2004-2006 \\
2004-2007 \\
2006-2007\end{array}$}} & 0.54 & 0.83 & 0.15 & 0.98 & & 0.42 \\
\hline & & 0.42 & $0.01^{*}$ & 0.62 & 0.75 & & $0.03^{*}$ \\
\hline & & 0.98 & 0.16 & 0.08 & 0.92 & & 0.50 \\
\hline
\end{tabular}



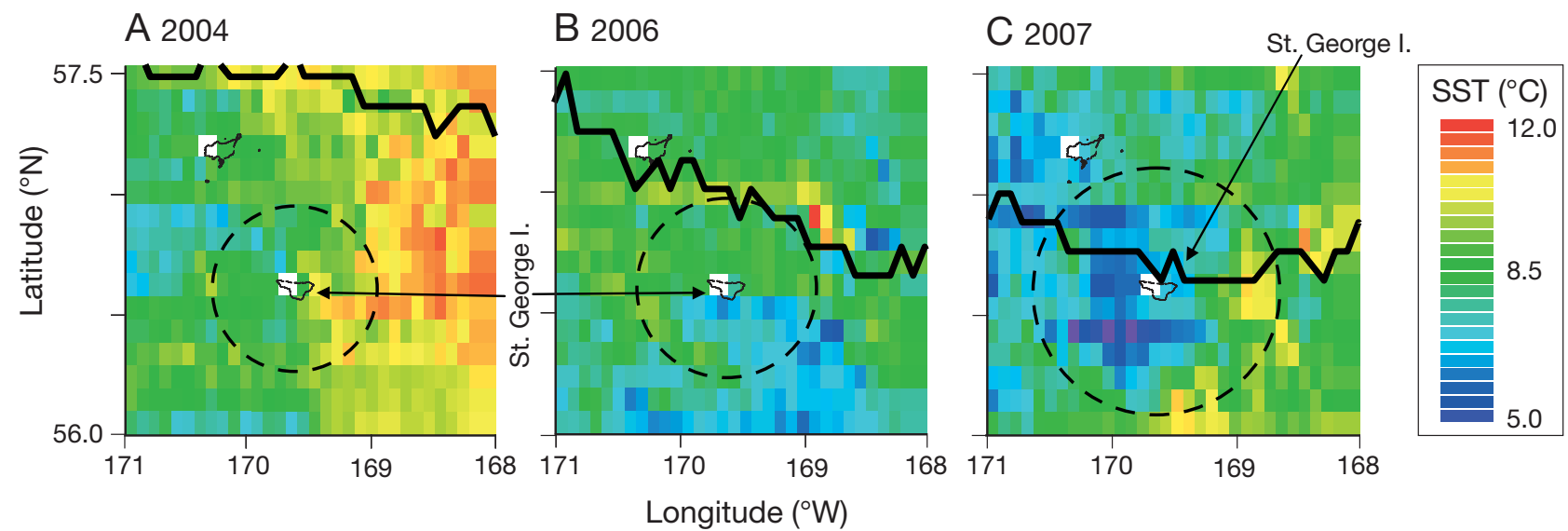

Fig. 1. Uria lomvia. Sea surface temperature (SST) during August and locations of the sea ice edge when ice reached its maximum extent during the former spring (bold black lines) obtained from satellite images around St. George Island, Bering Sea. Satellite data were downloaded from 'Multiple-Satellite Blended Products' on the Ocean Watch Homepage, National Oceanic and Atmospheric Administration (http://las.pfeg.noaa.gov/oceanWatch/oceanwatch.php). Mean SST \pm SD for $(\mathrm{A}) 2004=9.1 \pm 0.9^{\circ} \mathrm{C},(\mathrm{B})$ $2006=8.3 \pm 0.9^{\circ} \mathrm{C}$, and (C) $2007=7.8 \pm 1.4^{\circ} \mathrm{C}$ within the circles representing potential foraging range of the birds each year. Foraging range was estimated from total flight time multiplied by average flying speed ( $65 \mathrm{~km} \mathrm{~h}^{-1}$; Benvenuti et al. 1998). Dates of maximum ice extent were (A) 3 April in 2004, (B) 2 February in 2006, and (C) 22 March in 2007
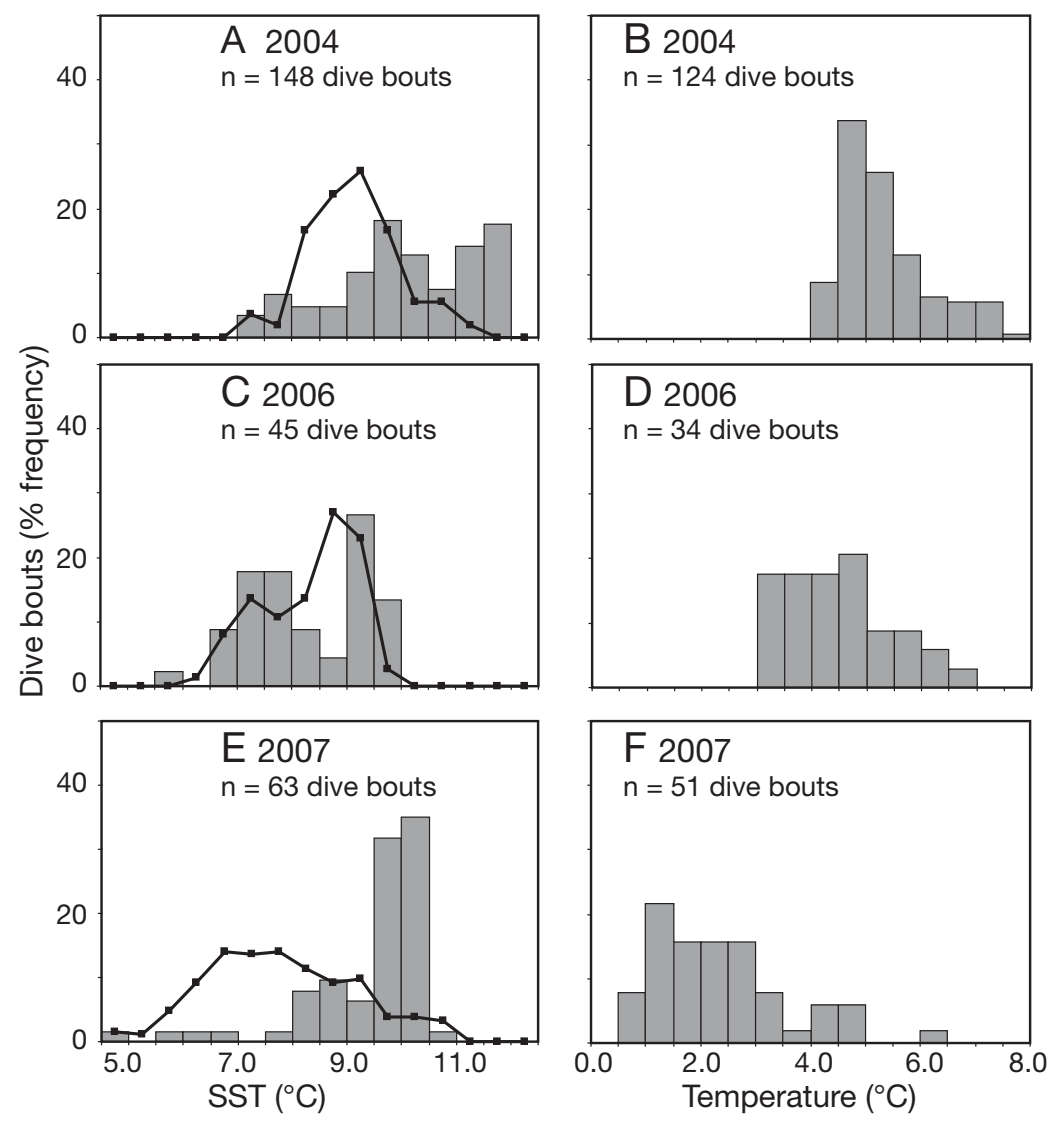

Fig. 2. Uria lomvia. Frequency distribution of dive bouts in relation to $(\mathrm{A}, \mathrm{C}, \mathrm{E})$ sea surface temperature ( $\mathrm{SST})$ and $(\mathrm{B}, \mathrm{D}, \mathrm{F})$ mean temperature at depth $>40 \mathrm{~m}$ in water column. Number of samples is shown in each figure. SST distributions from satellite data within the potential foraging range of birds also shown as line graphs in $(A, C, E)$. Only data for dive bouts with maximum dive depth $>40 \mathrm{~m}$ were used in $(B, D, F)$ and 2007, within a given range from the island (Fig. 3). The proportion of dive bouts in areas where a thermocline was recorded was also higher in 2004 and 2007, when thermocline intensity was greater, compared with 2006 when the thermocline intensity was lower (Table 2). Time spent diving per dive bout increased, on average, with SST in 2004 (Fig. $4 \mathrm{~A}_{;} \mathrm{R}^{2}=0.87, \mathrm{p}<0.01$ ) but not in 2006 and 2007 (Fig. 4B,C).

\section{Characteristics of diving behaviour}

The median depth of dives did not vary among years (Fig. 5B,F, J; Mood's median test, $\mathrm{df}=1: 2004$ vs. $2006: \mathrm{p}=$ $0.18,2004$ vs. $2007: \mathrm{p}=0.26,2006$ vs. 2007: $p=0.08$ ). The median depth of dives appeared to correlate with thermocline depth each year (Fig. 5B,F,J), although the correlation varied among years. In 2004, when SSTs, water temperature at depth, and thermocline intensity were greater, there was a single mode (ca. $30 \mathrm{~m}$ ) in depth of dives. In 2006, when the thermocline was weaker, the depth of dives was more variable (Fig. 5B,F; KolmogorovSmirnov test, $\mathrm{df}=2: \mathrm{p}=0.03$ ). In 2007, when a thermocline intensity was greater and water temperature at depth 
Table 2. Uria lomvia. Characteristics of the water columns where foraging dive bouts occurred in 2004, 2006 and 2007. Thermocline intensity: difference between average temperatures above and below the thermocline; No. of dive bouts: with or without thermocline; ${ }^{*} \mathrm{p}<0.05$

\begin{tabular}{|c|c|c|c|c|c|c|c|c|c|c|}
\hline \multirow{2}{*}{ Year } & \multicolumn{3}{|c|}{ — Temperature $\left({ }^{\circ} \mathrm{C}\right)$} & & \multicolumn{4}{|c|}{ Thermocline } & \multicolumn{2}{|c|}{ No. of dive bouts } \\
\hline & Surface & & $<40 \mathrm{~m}$ & & Depth (m) & & Intensity & & With & Without \\
\hline 2004 & 10.2 & & 5.1 & & 18 & & 4.2 & & 119 & 15 \\
\hline 2006 & 8.1 & & 4.4 & & 20 & & 2.9 & & 28 & 11 \\
\hline 2007 & 9.9 & & 2.2 & & 15 & & 5.7 & & 57 & 2 \\
\hline \multirow{2}{*}{$\begin{array}{l}\text { Interannual } \\
\text { comparison }\end{array}$} & \multicolumn{8}{|c|}{ Mood's median test $(\mathrm{df}=1)$} & \multicolumn{2}{|c|}{$\chi^{2}$ test $(\mathrm{df}=1)$} \\
\hline & $\chi^{2}$ & $\mathrm{p}$ & $\chi^{2}$ & $\mathrm{p}$ & $\chi^{2}$ & $\mathrm{p}$ & $\chi^{2}$ & $\mathrm{p}$ & $\chi^{2}$ & $\mathrm{p}$ \\
\hline $2004-2006$ & 53.0 & $<0.01^{*}$ & 9.6 & $<0.01^{*}$ & 0.4 & 0.53 & 3.8 & $0.050^{*}$ & 6.9 & $0.01^{*}$ \\
\hline $2004-2007$ & 4.3 & $0.04^{*}$ & 60.4 & $<0.01^{*}$ & 11.9 & $<0.01^{*}$ & 18.2 & $<0.01^{*}$ & 3.1 & 0.08 \\
\hline $2006-2007$ & 20.2 & $0.01^{*}$ & 49.3 & $0.01^{*}$ & 1.1 & 0.30 & 26.6 & $0.01^{*}$ & 12.6 & $<0.01^{*}$ \\
\hline
\end{tabular}

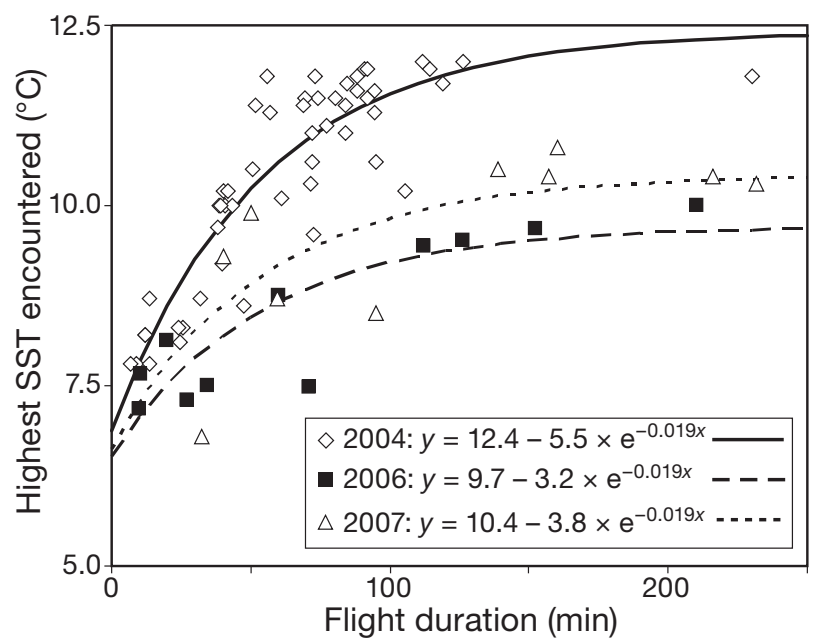

Fig. 3. Uria lomvia. Relationship between total flight duration during foraging trips and the highest sea surface temperature (SST) encountered by birds. Asymptotic exponential curves are fitted. Formulae for each curve regression for each year are shown

was lower, there were 2 modes in the distribution of depth of dives, one shallow at 15 to $25 \mathrm{~m}$ and one deeper at 65 to $75 \mathrm{~m}$ (Fig. 5B,J; Kolmogorov-Smirnov test, $\mathrm{df}=2: \mathrm{p}<0.01$ ). These differences among years in the association between dive depth and thermocline were obvious in the pattern of bottom time versus depth (Fig. 5C, G,K).

The association between dive depth and thermocline depth was examined more rigorously, by plotting the difference between dive depth and thermocline depth (Fig. 6). In 2004, diving was predominately to the thermocline and up to $20 \mathrm{~m}$ below it, whereas in 2006 the dives were dispersed over a wider depth range above and below the thermocline (Fig. 6A, $\mathrm{B}_{\text {; Kolmogorov- }}$ Smirnov test, $d f=2: p<0.01$ ). In 2007, the frequency of dive depths showed a clear peak near the thermocline

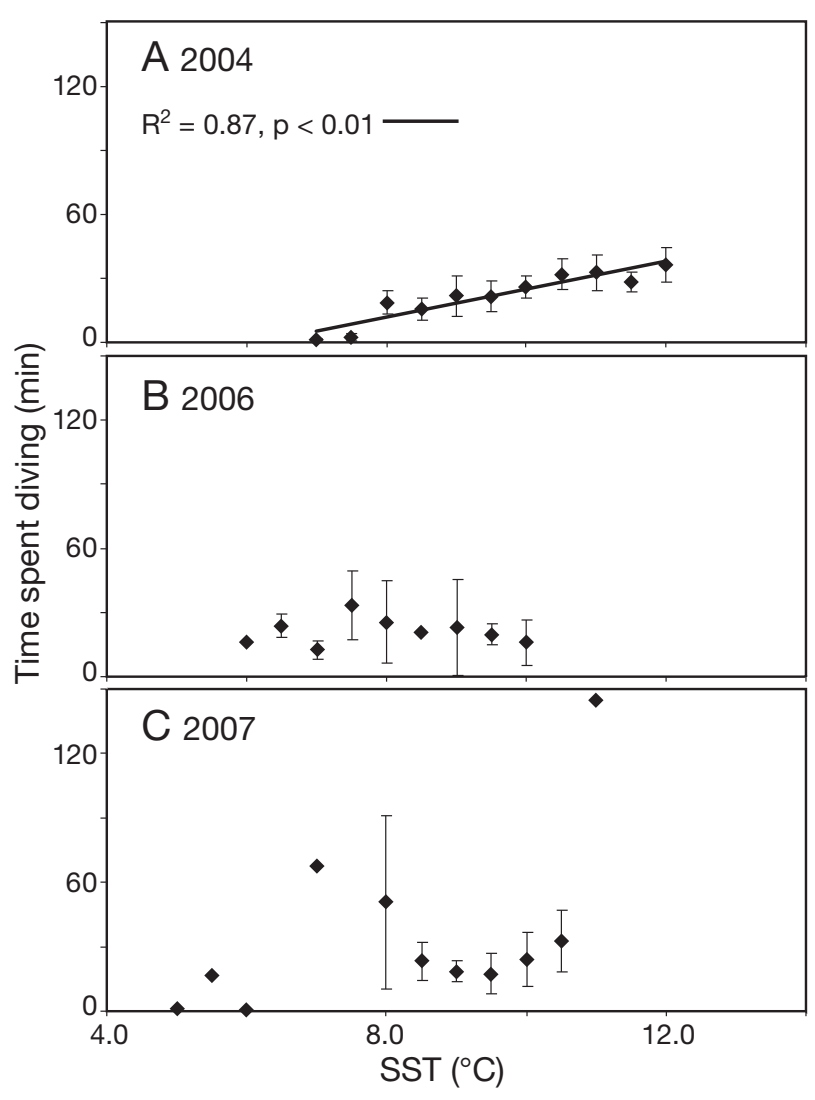

Fig. 4. Uria lomvia. Mean time \pm SE spent per foraging dive bout in relation to sea surface temperature (SST) in (A) 2004, (B) 2006 and (C) 2007. In (A), when a linear regression was observed, the regression line with $\mathrm{R}^{2}$ value is shown

depth (within $10 \mathrm{~m}$ above and below the thermocline), but there was also a second mode about 50 to $60 \mathrm{~m}$ below the thermocline (Fig. 6A, $C_{i}$ KolmogorovSmirnov test, $\mathrm{df}=2: \mathrm{p}<0.01$ ). In all 3 years, diving efficiency peaked at around $20 \mathrm{~m}$ and decreased with increasing depth (Fig. 5D,H,L). 

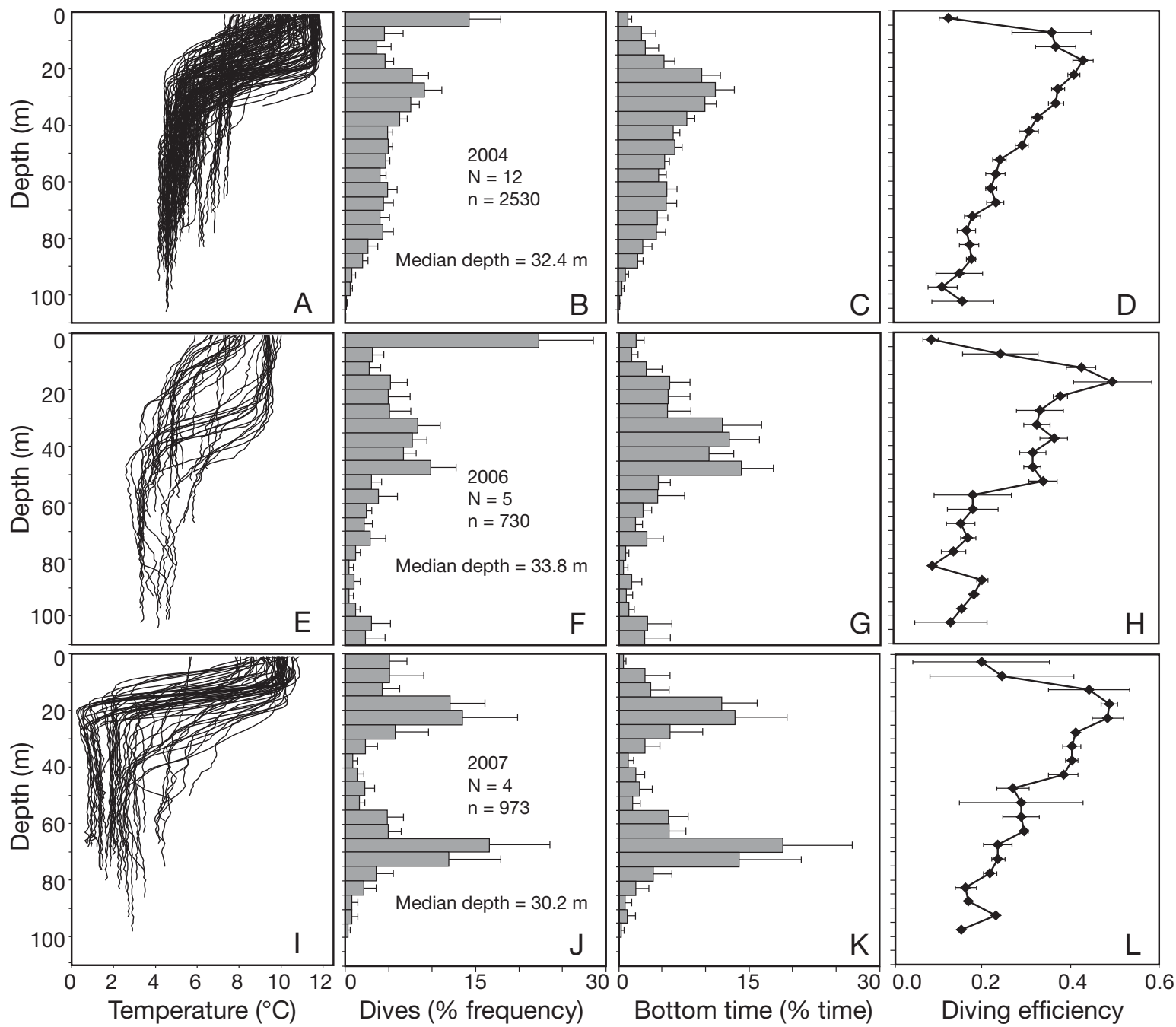

Fig. 5. Uria lomvia. (A,E,I) Vertical temperature profiles and diving behaviour of thick-billed murres with (B,F,J) frequency distribution of dives, $(C, G, K)$ percentage dive bottom time, and $(D, H, L)$ diving efficiency, in relation to dive depth. Panels are in the order (A to D) 2004, (E to H) 2006, and (I to L) 2007, from top to bottom. Means + SE are shown (except A,E,I), calculated using individual bird data. Sample number of birds (N), dives (n) and the median dive depth in each year are shown in (B,F,J) for 2004,2006 and 2007, respectively. In (A,E,I) all temperature profiles from each dive bouts are shown simultaneously. SST, thermocline depth, thermocline intensity, and water temperature at depth in each year are shown in Table 2
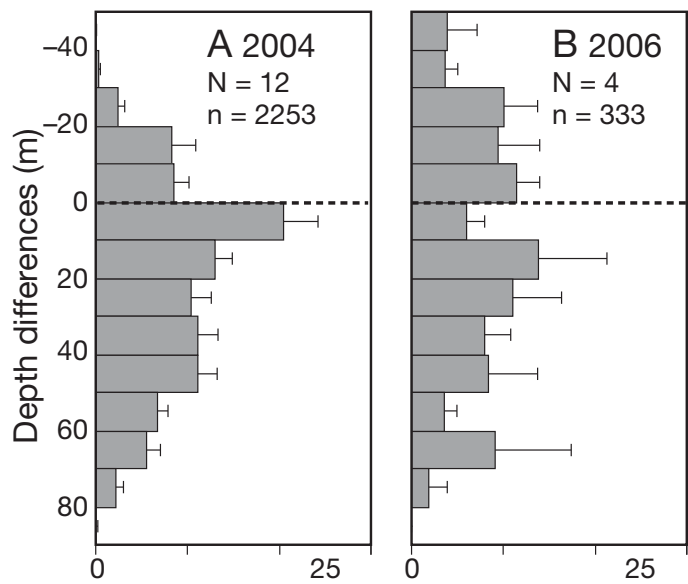

Dives (\% frequency)

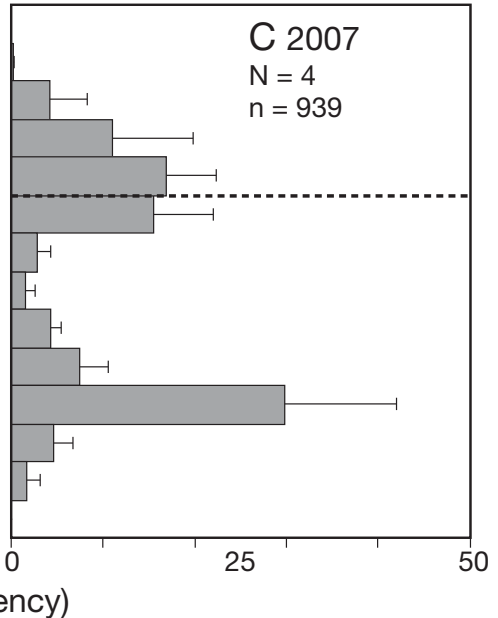

Fig. 6. Uria lomvia. Frequency distribution of dives in relation to the difference between dive depth and thermocline depth for (A) 2004, (B) 2006, and (C) 2007. Data are mean $\pm \mathrm{SE}$, calculated using individual bird data. Only dive data from dive bouts where a thermocline was observed were used for the analysis. Sample number of birds $(\mathrm{N})$, dives (n) and the median dive depth in each year are shown. Dashed line indicates location of the thermocline depth (shown as $0 \mathrm{~m}$ ) 
Table 3. Uria lomvia. Food items delivered to the chicks in 2004, 2006 and 2007. Data were collected by visual observation and identification was made during observation or later from photographs

\begin{tabular}{|c|c|c|c|c|c|c|}
\hline \multirow{2}{*}{ Food item } & \multicolumn{2}{|c|}{2004} & \multicolumn{2}{|c|}{$2006-$} & \multicolumn{2}{|c|}{2007} \\
\hline & Ind. & $\%$ & Ind. & $\%$ & Ind. & $\%$ \\
\hline Pacific sandlance Ammodytes hexapterus & 16 & 53.3 & 0 & 0.0 & 1 & 0.5 \\
\hline Walleye pollock Theragra chalcogramma & 7 & 23.3 & 9 & 18.0 & 30 & 15.6 \\
\hline Cephalopods (Gonatidae) & 3 & 10.0 & 14 & 28.0 & 118 & 61.5 \\
\hline Flatfishes (Pleuronectidae) & 0 & 0.0 & 10 & 20.0 & 6 & 3.1 \\
\hline Pricklebacks (Stichaeidae) & 0 & 0.0 & 2 & 4.0 & 8 & 4.2 \\
\hline Sculpins (Cottoidei) & 0 & 0.0 & 1 & 2.0 & 18 & 9.4 \\
\hline Others & 4 & 13.3 & 14 & 28.0 & 11 & 5.7 \\
\hline Total & 30 & 100.0 & 50 & 100.0 & 192 & 100.0 \\
\hline
\end{tabular}

\section{Diet}

We observed 30 prey items in 2004, 50 in 2006, and 192 in 2007 (Table 3). We identified them as Pacific sandlance Ammodytes hexapterus, walleye pollock Theragra chalcogramma, cephalopods (Gonatidae), flatfishes (Pleuronectidae), pricklebacks (Stichaeidae), sculpins (Cottoidei) and 'others'. The proportion of these prey items differed significantly among years (Table $3, \chi^{2}$ test, $\chi^{2}=187, \mathrm{df}=2, \mathrm{p}<0.01$ ). The proportion of the epibenthic fishes (flatfishes, pricklebacks and sculpins) was greater in 2006 (26.0\%) and 2007 $(16.9 \%)$ than in $2004(0.0 \%)$.

\section{DISCUSSION}

\section{Inter-annual variation in upper-ocean thermal structure around St. George Island}

During summer, upper-ocean thermal structure around the Pribilof Islands is characterized by 3 typical water masses (Kinder et al. 1983, Coachman 1986, Stabeno et al. 1999): 'coastal domain water' near the islands, which is well mixed tidally and has the lowest surface temperature; 'offshore domain water' far from the islands, which has cold bottom water, a strong thermocline and the highest surface temperature; and 'frontal domain water', which is located between the mixed nearshore waters and stratified offshore waters. The SST and temperature profiles recorded by the loggers attached on the foraging thick-billed murres suggest that the birds foraged in these different water masses near the colony (Figs. 2, 3, \& 5 present study, Takahashi et al. 2008).

Water temperatures recorded by both the loggers attached to the foraging birds and the satellite showed the inter-annual variation in the upper-ocean thermal structure around the island. The physical oceanographic conditions used by the birds each year was characterized by high SST, high water temperature at depth and a high thermocline intensity in 2004, a low thermocline intensity in 2006, and low water temperature at depth and a high thermocline intensity in 2007 (Fig. 2, Table 2). This may reflect annual variation in the degree of vertical mixing during summer and sea ice extent (degree of cooling) during the former winter and spring of each year (Overland et al. 1999, Stabeno et al. 2007). The comparatively northern location of the ice edge during spring 2004 (Fig. 1) may be linked to the high SST and water temperature at depth in 2004 (Fig. 2). On the other hand, the more southerly location of the ice edge in 2006 and 2007 (Fig. 1) may be linked with the relatively low SST and water temperature at depth in 2006 and 2007 (Fig. 2).

\section{Inter-annual variation in the foraging behaviour of the birds}

The thermocline was an important foraging habitat for the birds in all 3 years. Birds appeared to use areas where SSTs were higher (presumably the water was stratified by a thermocline; Kinder et al. 1983) compared with the patterns of SST observed by earth-orbiting satellites, especially in 2004 and 2007 (Fig. 2A,C,E). Birds frequently used areas where a thermocline was observed and the peak diving depth was approximately thermocline depth. This highlights the importance of the thermocline (Fig. 5, Table 2). The thermocline was more important as a foraging habitat for thick-billed murres in 2004 and 2007 when an intense thermocline occurred compared with a much weaker thermocline in 2006 (Fig. 6, Table 2). In 2004, birds spent more time in areas where SSTs were higher, where the thermocline possibly developed (Fig. 4). In 2004 and 2007 the peak diving depth was near the thermocline (Fig.6). Around the Pribilof Islands the thermocline is one of the main habitats for small fishes such as first year walleye pollock, the main prey of murres 
(Schabetsberger et al. 2000, 2003, Kokubun et al. 2008). No information on depth distribution of Pacific sandlance around St. George Island (the other main prey in 2004) was available, however a study from another area suggests that thick-billed murres tend to make shallow dives $(<60 \mathrm{~m})$ when feeding on Pacific sandlance compared with other fishes (Elliott et al. 2008).

The intensity of the thermocline and water temperature below $40 \mathrm{~m}$ might be factors affecting annual variation in foraging behaviour of thick-billed murres. In 2006 a weak thermocline occurred and the association of dive depths with thermocline depth appeared to be weaker than in 2004 and 2007. In 2006, birds used areas without a thermocline more frequently than in 2004 and 2007 (Table 2), and even in areas where a thermocline was observed, the diving depth was widely dispersed about the thermocline (Fig. 6). In 2007, however, when water temperature at depth was lower, birds dived deeper more often, and to the thermocline (Fig. 6). In 2006 and 2007, when birds ate cephalopods and epibenthic fishes (flatfishes, pricklebacks and sculpins), prey availability just below the thermocline might have been lower than in 2004 or the prey availability at greater depths might have been higher than in 2004. Larger fishes (e.g. 1 year old pollock) are distributed at greater depths than smaller ones (Winter \& Swartzman 2006). These large prey were sometimes observed in stomach contents of thick-billed murres breeding at St. George Island (Schneider et al. 1990, Decker \& Hunt 1996, Dragoo et al. 2008, Ito et al. 2010, this issue). The depth distribution of cephalopods around the Pribilof Islands is poorly known, but Elliott et al. (2008) suggested that thick-billed murres dive deeper $(>90 \mathrm{~m})$ when they feed on cephalopods elsewhere. The variation in dive depths versus thermocline depth in 2006 and 2007 could mean that birds chose to forage on prey species at other depths (cephalopods and benthic fishes; Table 3) rather than species distributed near the thermocline (age-0 walleye pollock and Pacific sandlance).

The observed variation in diving depth among years might be related to energy expenditure versus energy gain while foraging. Diving efficiency was greater for shallow dives, just below the thermocline (observed in 2004) or above the thermocline (partially observed in 2006 and 2007), than for deeper dives (Fig. 5D,H,L). Shallower dives need less time for descent, ascent, and the post-dive surface interval than do deeper dives, thus their diving efficiency is relatively high (Mori et al. 2002). On the other hand, birds may have caught larger prey when they made deeper dives (mainly observed in 2007). In the Atlantic Ocean, common murres Uria aalge frequently dive to deep $(>100 \mathrm{~m})$ and cold water $\left(<0^{\circ} \mathrm{C}\right)$ to feed on large capelin Mallotus villosus which are energy rich and slow swimmers (Hedd et al. 2009). Around the Pribilof Islands, larger fishes (e.g. $1 \mathrm{yr}$ pollock), which are likely to have a higher energy value, are distributed at greater depths than smaller ones (e.g. first year pollock; Winter \& Swartzman 2006). Birds may have dived deeper in 2006 or 2007 to catch larger prey.

The results of our study, together with those from previous studies of the Bering Sea ecosystem, imply a correlation between SST, water temperature at depth, thermocline intensity and the foraging behaviour of murres. The marine ecosystem of the Bering Sea shelf has experienced series of both cold and warm climate regimes in the last 2 to 3 decades (Stabeno et al. 2007, Hunt et al. 2008). Changes in upper-ocean thermal structure with these climate regimes lead to changes in the abundance, distribution and species composition of fishes. Hunt et al. (2008) suggested that production of small species of copepods (which are important prey for juvenile pelagic fish) is higher during the warm regime when the water column is more strongly stratified. Mueter \& Litzow (2008) suggested that the expansion of cold bottom water causes changes in the abundance and species composition of benthic fish and that 'Arctic' fish species have good recruitment under the cold regime. We think that the availability of prey, such as small fishes, is high near the thermocline during warm conditions (as observed in 2004), but that a shift from warm to cold regimes might reduce availability of prey near the thermocline or increase the availability of prey at depth. Thus, it seems likely that murres change their geographic foraging habitats (from areas with a thermocline to coastal or frontal areas without a thermocline, as observed in 2006), or vertical foraging habitats (from a peak around the thermocline depth to a dispersed depth range as observed in 2006, or to a second depth zone, deeper than the thermocline as observed in 2007). However, reproductive success of thick-billed murres at St. George Island did not differ among the study years (number of chick fledged/number of eggs: $0.46,0.44,0.52$, in 2004, 2006, 2007, respectively; Shannon et al. 2009), despite the inter-annual variation in water temperature, prey items and foraging behaviour of the birds. Indeed the dynamic nature of the foraging tactics of murres, relative to changes in ocean thermal structure and correlative changes in abundance and distribution of prey, might have facilitated consistent reproductive success. Thus, while the thermocline remained an important foraging habitat for thick-billed murres during all 3 years of this study, the availability and forms of prey at other depths might have been an important buffering influence on foraging and reproductive success.

In conclusion, we found a correlation between foraging behaviour of thick-billed murres and the upper- 
ocean thermal structure. The birds often dived near the thermocline but the association of dives with the thermocline varied with the intensity of the thermocline. In years when water below the thermocline was colder, the birds often dived below the thermocline. We also found significant differences in the diets of foraging murres. Overall, the foraging behaviour of thickbilled murres appeared to correlate with annual variability in thermocline intensity and water temperature at depth and the presumed correlative influences on the availability of prey.

Acknowledgements. We thank Karin Holser, Vernon Byrd, Ramuel Papish, and the other staff of the US Fish and Wildlife Service for their logistic support and helpful advice in the field at St. George Island. We also thank Dr. George L. Hunt and 2 anonymous reviewers who provided helpful suggestions and comments which improved the manuscript. This work was supported by a 21st century COE program (NeoScience of Natural History, lead by H. Okada), and partially supported by Research Fellowships for Young Scientists of the Japan Society for the Promotion of Sciences (JSPS) awarded to N.K. and A.T., a NPRB grant \#RO320 awarded to A.S.K., and by a National Science Foundation grant OPP0327308 awarded to Dr. George L. Hunt. A.S.K. received support from Alaska EPSCoR (NSF \#EPS-0346770).

\section{LITERATURE CITED}

Ballance LT, Ainley DG, Hunt GL (2001) Seabird foraging ecology. In: Steele JH, Thorpe SE, Turekian KK (eds) Encyclopedia of ocean sciences. Academic Press, San Diego, CA, p 2636-2644

Benvenuti S, Bonadonna F, Dall'Antonia L, Gudmundsson GA (1998) Foraging flights of breeding thick-billed murres (Uria lomvia) as revealed by bird-borne direction recorders. Auk 115:57-66

Byrd GV, Sydeman WJ, Renner HM, Minobe S (2008) Responses of piscivorous seabirds at the Pribilof Islands to ocean climate. Deep-Sea Res II 55:1856-1867

Charrassin JB, Bost CA (2001) Utilisation of the oceanic habitat by king penguins over the annual cycle. Mar Ecol Prog Ser 221:285-297

> Coachman LK (1986) Circulation, water masses and fluxes on the southeastern Bering Sea Shelf. Cont Shelf Res 5:23-108

- Daunt F, Peters G, Scott B, Gremillet D, Wanless S (2003) Rapid-response recorders reveal interplay between marine physics and seabird behaviour. Mar Ecol Prog Ser 255:283-288

Daunt F, Wanless S, Peters G, Benvenuti S, Sharples J, Gremillet D, Scott B (2006) Impacts of oceanography on the foraging dynamics of seabirds in the North Sea. In: Boyd I, Wanless S, Camphuysen CJ (eds) Top predator in marine ecosystems: their role in monitoring and management. Cambridge University Press, Cambridge, p 177-190

Decker MB, Hunt GL Jr (1996) Foraging by murres (Uria spp.) at tidal fronts surrounding the Pribilof Islands, Alaska, USA. Mar Ecol Prog Ser 139:1-10

Decker MB, Hunt GL, Byrd GV (1995) The relationships among sea-surface temperature, the abundance of juvenile walleye pollock (Theragra charcogramma), and the reproductive performance and diets of seabirds at the Pribilof Islands, southeastern Bering Sea. Can Spec Publ Fish
Aquat Sci 121:425-437

Dragoo DE, Byrd V, Irons DB (2008) Breeding status, population trends and diets of seabirds in Alaska, 2005. US Fish Wildl Serv Res Rep AMNWR 08/03. US Fish and Wildlife Service, Homer, AK, p 53-57

Elliott KH, Woo K, Gaston AJ, Benvenuti S, Dall'Antonia L, Davoren GK (2008) Seabird foraging behaviour indicates prey type. Mar Ecol Prog Ser 354:289-303

Falk K, Benvenuti S, Dall'Antonia L, Kampp K, Ribolini A (2000) Time allocation and foraging behaviour of chickrearing Brünnich's guillemots Uria lomvia in high-arctic Greenland. Ibis 142:82-92

> Hedd A, Regular PM, Montevecchi WA, Buren AD, Burke CM, Fifield DA (2009) Going deep: common murres dive into frigid water for aggregated, persistent and slow-moving capelin. Mar Biol 156:741-751

Hunt GL, Burgeston B, Sanger GA (1981) Feeding ecology of seabirds of the eastern Bering Sea. In: Hood DW, Calcler JA (eds) The Bering Sea Shelf: oceanography and resources, Vol. II. University of Washington Press, Seattle, WA, p 629-648

Hunt GL, Eppley GA, Schneider DC (1986) Reproductive performance of seabirds: the importance of population and colony size. Auk 103:306-317

Hunt GL, Harrison NM, Cooney RT (1990) Foraging of least Auklets: the influence of hydrographic structure and prey abundance. Stud Avian Biol 14:7-22

Hunt GL Jr, Stabeno PJ, Storm S, Napp JM (2008) Patterns of spatial and temporal variation in the marine ecosystem of the southeastern Bering Sea, with special reference to the Pribilof Domain. Deep-Sea Res II 55:1919-1944

> Ito M, Takahashi A, Kokubun N, Kitaysky AS, Watanuki Y (in press) (2010) Flexible foraging strategies of incubation and chick-rearing thick-billed murre. Aquat Biol 8:279-287

Kinder TH, Hunt GL, Schneider D, Schumacher JD (1983) Correlations between seabirds and oceanic fronts around the Pribilof Islands, Alaska. Estuar Coast Shelf Sci 16: 309-319

Kitaysky AS, Hunt GL, Flint EN, Rubega MA, Decker MB (2000) Resource allocation in breeding seabirds: response to fluctuation in their food supply. Mar Ecol Prog Ser 206: 283-296

Kokubun N, Iida K, Mukai T (2008) Distribution of murres (Uria spp.) and their prey south of St. George Island in the southeastern Bering Sea during the summers of 2003-2005. Deep-Sea Res II 55:1827-1836

> Mori Y, Takahashi A, Mehlum F, Watanuki Y (2002) An application of optimal diving models to diving behavour of Brünnich's guillemots. Anim Behav 64:739-745

> Mueter FJ, Litzow MA (2008) Sea ice retreat alters the biogeography of the Bering Sea continental shelf. Ecol Appl 18:309-320

Overland JE, Salo SA, Kantha LH, Clayson CA (1999) Thermal stratification and mixing on the Bering Sea shelf. In: Loughlin TR, Ohtani K (eds) Dynamics of the Bering Sea. University of Alaska Sea Grant, Fairbanks, AK, p 129-146

Overland JE, Wang M, Ladd C, Stabeno PJ, Bond N, Salo SA (2008) Appendix C Eastern Bering Sea Climate-FOCI. In: Boldt J (ed) Ecosystem consideration for 2009: Alaska Fisheries Science Center Resource Ecology and Ecosystem Modeling. North Pacific Fishery Management Council, Anchorage, AK, p 47

Schabetsberger R, Brodeur RD, Ciannelli L, Napp JM, Swartzman GL (2000) Diel vertical migration and interaction of zooplankton and juvenile walleye Pollock (Theragra chalcogramma) at a frontal region near the Pribilof Islands, Bering Sea. ICES J Mar Sci 57:1283-1295 
Schabetsberger R, Sztatecsny M, Drozdowski G, Brodeur RD and others (2003) Size-dependent, spatial, and temporal variability of juvenile walleye Pollock (Theragra chalcogramma) feeding at a structural front in the Southeast Bering Sea. PSZN I: Mar Ecol 24:141-164

Schneider DC, Harrison NM, Hunt GL (1990) Seabird diet at a front near the Pribilof Islands, Alaska. Stud Avian Biol 14:61-69

Shannon P, Drummond B, Thomsen S (2009) Results of seabird monitoring at St. George Island, Alaska in 2009: summary appendices. US Fish Wildl Serv Res Rep AMNWR 09/xx. US Fish and Wildlife Service, Homer, AK, p 55-57

Sinclair EH, Vlietstra LS, Johnson DS, Zeppelin TK and others (2008) Patterns in prey use among fur seals and seabirds in the Pribilof Islands. Deep-Sea Res II 55:1897-1918

Sowls AL, Hatch SA, Lensink CJ (1978) Catalog of Alaskan seabird colonies. US Fish and Wildlife Service, Washington, DC

Spear LB, Ballance LT, Ainley DG (2001) Response of seabirds to thermal boundaries in the tropical Pacific: the thermocline versus the Equatorial Front. Mar Ecol Prog Ser 219: 275-289

Stabeno PJ, Schumacher JD, Salo SA (1999) Physical environment around the Pribilof Islands. In: Loughlin TR, Ohtani $\mathrm{K}$ (eds) Dynamics of the Bering Sea. University of Alaska Sea Grant, Fairbanks, AK, p 193-215

Stabeno PJ, Bond NA, Salo SA (2007) On the recent warming of the southeastern Bering Sea shelf. Deep-Sea Res II 54:

Submitted: August 5, 2009; Accepted: March 5, 2010
$2599-2618$

Takahashi A, Matsumoto K, Hunt GL, Shultz MT and others (2008) Thick-billed murres use different diving behaviors in mixed and stratified waters. Deep-Sea Res II 55: $1837-1845$

Takahashi A, Dunn MJ, Trathan PN, Sato K, Naito Y, Croxall JP (2003) Foraging strategies of chinstrap penguins at Signy Island, Antarctica: importance of benthic feeding on Antarctic krill. Mar Ecol Prog Ser 250:279-289

Tremblay Y, Cherel Y, Oremus M, Tveraa T, Chastel O (2003) Unconventional ventral attachment of time-depth recorders as a new method for investigating time budget and diving behaviour of seabirds. J Exp Biol 206:1929-1940

Watanuki Y, Mehlum F, Takahashi A (2001) Water temperature sampling by Brunnich's guillemots with bird-borne data loggers. J Avian Biol 32:189-193

Watanuki Y, Wanless S, Harris M, Lovvorn JR, Miyazaki M, Tanaka H, Sato K (2006) Swim speeds and stroke patterns in wing-propelled divers: a comparison among alsids and a penguin. J Exp Biol 209:1217-1230

Winter AG, Swartzman GL (2006) Interannual changes in distribution of age- 0 walleye pollock near the Pribilof Islands, Alaska, with reference to the prediction of pollock yearclass strength. ICES J Mar Sci 63:1118-1135

Wyllie-Echeverria T, Ohtani K (1999) Seasonal sea ice variability and the Bering Sea ecosystem. In: Loughlin TR, Ohtani K (eds) Dynamics of the Bering Sea. University of Alaska Sea Grant, Fairbanks, AK, p 435-451

Proofs received from author(s): March 12, 2010 